\title{
Malignant pilomatricoma
}

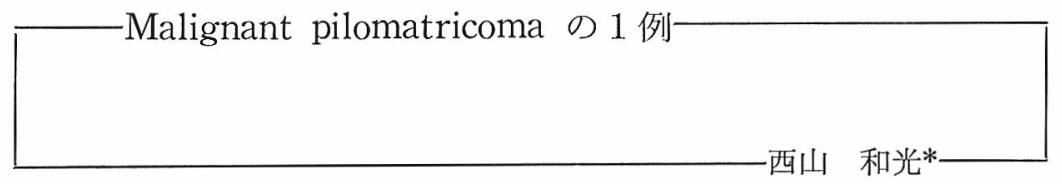

\section{Summary}

74 歳, 男性の左後頸部に 3 年前から生じた紅色結節 $(7 \times 8 \times 6 \mathrm{~mm})$ を切除し, 組織学 的に検討した。腫瘍は表皮と連続せず真皮から脂肪織にかけて霊腫状に存在し，腫瘍細胞 は basaloid cell, shadow cell, squamoid cell などからなり pilomatricoma 飞特有の構 築を示すとともに basaloid cell 巣は pilomatricoma のそれより泡洙状で大きな核で多 数の mitosis 像を伴い, squamoid cell 巣は部位により不規則に間質への浸潤增殖傾向を 示した。従来の報告に合致する組織所見からその早期例と考兄られ報告した。腫瘍内にみ られる異物反応様の部は良性例の場合と異なり腫瘍の浸潤傾向の表現としてとら兄られる 必要があると考完た。

\section{緒}

\section{言}

1927 年の Gromiko の報告1) 以来, pilomatricoma の悪性化例または再発性進行性の例は, 種々の名称で報告されてきた。Lopansri \&

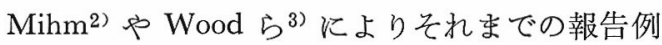
の総括がなされたのち 1984 年に Gould ら4) よる肺転移例の報告もなされて特り malignant pilomatricoma という疾患の存在は確立された と考光られる。私もこの稀有な疾患の早期例を 経験したので報告する。

\section{症例}

患 者：74歳, 男性, 漁師

初 診：昭和62年 1 月 16 日

* Kazumitsu NISHIYAMA：国立山口病院皮首 科

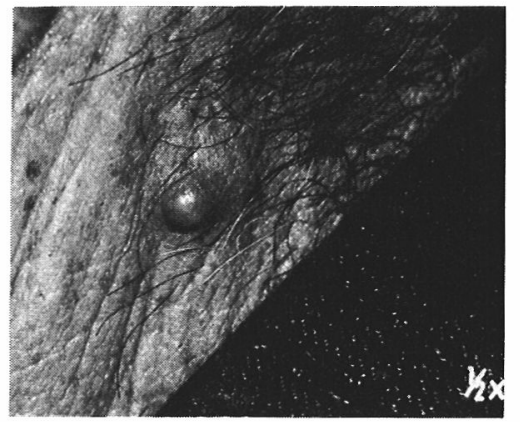

図 1.

現病歴： 3 年前より左後頸部に小腫瘤が生じ 半年前から徐々に増大してきた。

臨床所見 : $7 \times 8 \times 6 \mathrm{~mm}$ 大の表面平滑で球状 に隆起した暗紅色結節で下床との癒着なし（図 $1)$ 。

組織所見: 表皮との連続なく真皮浅層から脂 肪織にかけて囊腫状の腫瘍が認められた。腫瘍 細胞の増殖様式は pilomatricomaにみられると 類似し basaloid cell の增殖部, shadow cell の 


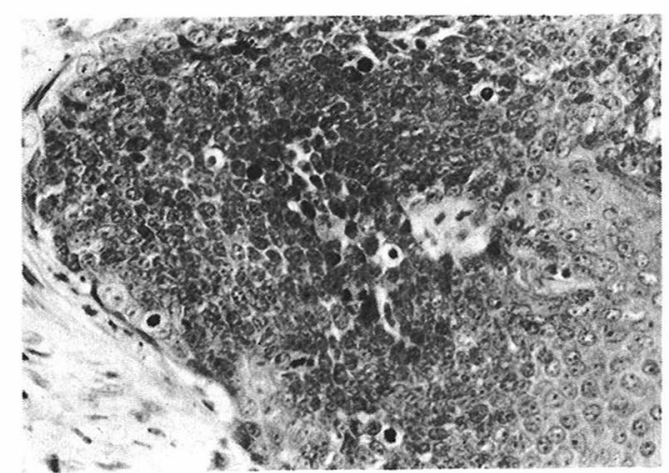

図 2.

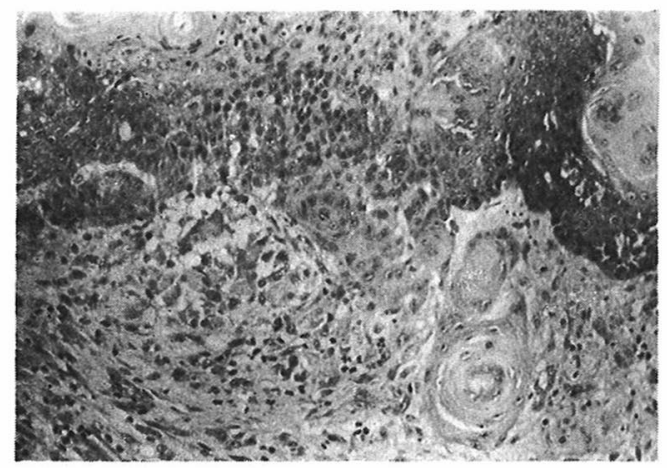

図3.

増殖部，それらの移行部の細胞の増殖部の他に squamoid cell の增殖部, 澄明細胞の增殖部など が混在し, 変性した細胞や異物型巨細胞を混じ 光た炎症細胞浸潤を伴っていた。Basaloid cell の增殖部では核は pilomatricoma にみられるも のより泡沫状で大きく, 多数の mitosis 像が認 められた（図 2)。Basaloid cell は移行細胞を へて shadow cell につついたものや，大小のト リコヒアリン様顆粒をもった squamoid cell 澄明細胞をへて硝子様角化ないし顆粒状角化様 物につづたものや原のま変性に陥ったもの などが認められた。一部では squamoid cell が 真皮内に不規則に増殖した部もみられた（図 3 )。腫瘍と間質との境界はしばしば shadow cell の増殖部などが遊離した形となり異物巨細 胞などの浸潤が強く, 腫瘍の浸潤がどこまでか 不明瞭であったが，比較的異物反応の少ない部 ではときに mitosis 像を混じえて, squamoid cell

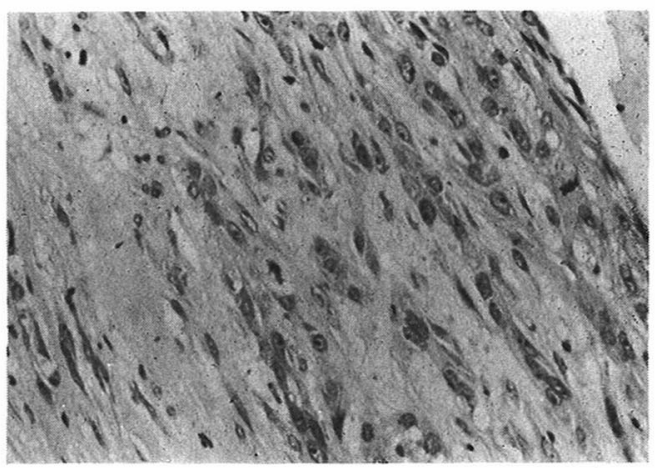

図 4.

が細長くなり索状に交錯して間質を混じえて数 層に増殖しているのが認められた（図 4 ）。

治療および経過 : 初診時, 紅色結節の辺縁よ り $5 \mathrm{~mm}$ 離して切除した。組織所見を検討のの ち再び $1 〜 2 \mathrm{~cm}$ 離して脂肪織までを全摘した。 術後 6 力月経過の時点で再発は認められていな w。

\section{考察}

Malignant pilomatricoma は現在までに少な くとも13例の報告がみられている(表 1 $)^{1) ~ 12) 。 ~}$ それらは良性例に比べて, 細胞異型が強く mitosis 像が著しく多いとされ，臨床的にも局所悪 性が強く，遠隔転移例( ) も報告されている。自 験例は従来の報告と同様の組織所見を呈した早 期例と考号られた。腫瘍の一部では squamoid cell が紡錘状となり索状に連なり不規則に交錯 して真皮に浸潤する傾向が認められたが，この 点について以下のように考察した。腫瘍と間質 との境界は弱拡大では一見, 結合織性の被膜様 構造で囲まれているよらにみえたが詳細観察 すると腫瘍細胞と炎症性細胞浸潤との境界は不 明瞭であった。とくに shadow cell の増殖部が 断片状に存在する部ではそれに対する単なる異 物反応なのか腫瘍の浸潤に対する免疫学的反応 なのか判断に困る場合が多かったが，異物反応 の少ない部でのこのよらな索状の増殖は時折り 混在する mitosis 像とともに腫瘳の浸潤の初期 
表 1. Malignant pilomatricoma and pilomatricoma with aggressive behavior

\begin{tabular}{|c|c|c|c|c|c|c|}
\hline Source, yr & $\begin{array}{l}\text { Age, yr/ } \\
\text { Sex }\end{array}$ & $\underset{\text { Location }}{\text { Tumor Size, }} \mathrm{cm}$, & $\left|\begin{array}{l}\text { Dura- } \\
\text { tion, yr }\end{array}\right|$ & $\begin{array}{c}\text { First } \\
\text { Treatment }\end{array}$ & Follow-up & $\begin{array}{l}\text { Treatment of } \\
\text { Recurrence }\end{array}$ \\
\hline Gromiko, & $32 / \mathrm{M}$ & Small, $\mathrm{R}$ arm & $?$ & Excision & $\begin{array}{l}\text { Recurrence twice } \\
\text { in } 12 \mathrm{yr} \text { to size } \\
\text { of } 13.5 \mathrm{~cm}\end{array}$ & $\begin{array}{l}\text { Wide excisions } \\
\text { and amputation }\end{array}$ \\
\hline $\begin{array}{l}\text { Prandetsky and } \\
\text { luzuinkevich, } 1969\end{array}$ & $52 / \mathrm{F}$ & 3, L hip & 1 & Excision & Not reported & $\cdots$ \\
\hline Krausen et al., 1974 & $47 / \mathrm{M}$ & 7, L auricular & 6 & $\begin{array}{l}\text { Modified } \\
\text { parotidectomy }\end{array}$ & $\begin{array}{l}\text { No follow-up } \\
\text { evaluation }\end{array}$ & $\cdots$ \\
\hline Rothman et al., 1976 & $56 / \mathrm{F}$ & $\begin{array}{l}\text { 13. } 5 \text {, L pre- } \\
\text { auricular }\end{array}$ & 5 & $\begin{array}{l}\text { Partial parotid } \\
\text { and auricular } \\
\text { removal }\end{array}$ & $\begin{array}{l}\text { No recurrence } \\
\text { (up to 1979) }\end{array}$ & $\cdots$ \\
\hline Sasaki et al., 1976 & $21 / \mathrm{M}$ & $\begin{array}{l}\text { 3, } \mathrm{R} \text { preauri- } \\
\text { cular }\end{array}$ & 4 & $\begin{array}{l}\text { Excision with } \\
\text { flap }\end{array}$ & $\begin{array}{l}\text { Recurrence in } \\
3 \mathrm{yr}\end{array}$ & $\begin{array}{l}\text { Resection of } \\
\text { auricle, parotid, } \\
\text { and adjacent } \\
\text { bones }\end{array}$ \\
\hline $\begin{array}{l}\text { Lopansri and Mihm, } \\
1980\end{array}$ & $35 / \mathrm{M}$ & $\underset{\text { back }}{1.5, \mathrm{R} \text { upper }}$ & 1 & Excision & $\begin{array}{l}\text { Recurrence } \\
\text { twice in } 3 \text { yr }\end{array}$ & $\begin{array}{l}\text { Wide reexcisions } \\
\text { and radiothera- } \\
\text { py }\end{array}$ \\
\hline \multirow[t]{2}{*}{ Weeden et al., 1980} & $93 / \mathrm{M}$ & $\begin{array}{l}\text { 1. } 2, \mathrm{~L} \text { pre- } \\
\text { auricular }\end{array}$ & Few & $\begin{array}{l}\text { Radiotherapy } \\
(2,000 \mathrm{rad})\end{array}$ & $\begin{array}{l}\text { No recurrence } \\
\text { in } 1 \mathrm{yr}\end{array}$ & $\cdots$ \\
\hline & $80 / \mathrm{M}$ & $\begin{array}{l}\text { 1. } 3, \mathrm{~L} \text { lower } \\
\text { eyelid }\end{array}$ & $1 \mathrm{yr}$ & Excision & $\begin{array}{l}\text { No recurrence } \\
\text { in } 6 \mathrm{mo}\end{array}$ & $\cdots$ \\
\hline Takeishi et al., 1982 & $45 / \mathrm{M}$ & $\begin{array}{c}\text { Thumb R } \\
\text { temporal }\end{array}$ & 5 & Excision & $\begin{array}{l}\text { Recurrence } 3 \\
\text { time in } 1 \mathrm{yr} \\
6 \mathrm{mo}\end{array}$ & $\begin{array}{l}\text { Reexcision } \\
\text { radiotheray } \\
\text { chemotherapy }\end{array}$ \\
\hline Wood et al., 1984 & $86 / \mathrm{M}$ & $\begin{array}{l}\text { 1. } 4, \mathrm{R} \text { post- } \\
\text { cervical }\end{array}$ & $3 \mathrm{mo}$ & Curetted & $\begin{array}{l}\text { Died before fur- } \\
\text { ther investiga- } \\
\text { tion was possible }\end{array}$ & $\cdots$ \\
\hline Gould et al., 1984 & $67 / \mathrm{M}$ & $\begin{array}{l}\text { 5, Upper back } \\
\text { (recurrence) }\end{array}$ & ? & Excision & $\begin{array}{l}\text { Recurrence } \\
\text { twice in } 4 \mathrm{yr} \\
\text { pulmonary me- } \\
\text { tastases in } 2 \mathrm{yr}\end{array}$ & $\begin{array}{l}\text { Excision } \\
\text { radiotherapy } \\
\text { L-thoracotomy }\end{array}$ \\
\hline $\begin{array}{l}\text { Kuwahara et al., } \\
1984\end{array}$ & ? & $2.1, \quad ?$ & $2 \mathrm{mo}$ & ? & ? & \\
\hline Sato et al., $\quad 1985$ & $41 / \mathrm{F}$ & 1. 1, R cheek & $1 \mathrm{mo}$ & Excision & $\begin{array}{l}\text { No recurrence } \\
\text { in } 8 \mathrm{mo}\end{array}$ & \\
\hline Present case 1987 & $74 / \mathrm{M}$ & $\begin{array}{l}0.8, \mathrm{~L} \text { postcer- } \\
\text { vical }\end{array}$ & 3 & Excision & $\begin{array}{l}\text { No recurrence } \\
\text { in } 4 \mathrm{mo}\end{array}$ & \\
\hline
\end{tabular}

（Woodらの報告に追加）

所見と考光られた。すなわち良性例では異物反 応として説明されている巨細胞を混じえた細胞 浸潤が malignant pilomatricoma に扔いてはそ のような部が腫瘍の浸潤と密接に関連したもの としてとらえられる必要性を示唆しており, 切 除に際して異物反応様部を含めた十分な摘出が
再発防止のために重要と考えた。

\section{文献}

1) Gromiko, N.: Zür Kenntnis der Bosartigen unwandlung des Verkalkten Hautepitheliomas. Arch. Pathol. Anat., 265: 103-116, 1927.

2) Lopansri, S., Mihm, M.C. Jr.: Pilomatrix- 
carcinoma or calcifying epitheliocarcinoma of Malherbe. Cancer, 45: 2368-2373, 1980.

3) Wood, M.G., Parhizgar, B., Beerman, H.: Malignant pilomatricoma. Arch. Dermatol., 120: 770-773, 1984.

4) Gould, E., Kurzon, R., Kowalczyk, A.P., Saldana, M.: Pilomatrix carcinoma with pulmonary metastasis. Cancer, 54: 370-372, 1984.

5) Prandetsky, A.P., Yuzvinkevich, A.K.: Malherbe's epithelioma with sign of malignization. Arch. Pathol., 31: 64-66, 1966.

6) Krausen, A.S., Ansel, D.G., Mays, B.R.: Pilomatrixoma masquerading as a parotid mass. Laryngoscope, 84: 528-538, 1974.

7) Rothman, D., Kendall, A.B., Baldi, A.: Giant pilomatrixoma (Malherbe calcifying epithe- lioma). Arch. Surg., 111: 86-87, 1976.

8) Sasaki, C.T., Yue, A., Enriques, R.: Giant calcifying epithelioma. Arch. Otolaryngol., 102: 753-755, 1976.

9) Weeden, D., Bell, J., Mayze, J.: Matrical carcinoma of the skin. J. Cutan. Pathol., 7: $39-42,1980$.

10）武石正昭, 占部治邦, 幸田 弘：Matrical carcinoma of the skin. 西日本皮膚科，44：127， 1982.

11）桑原宏始, 奥村之啓, 宮脇由美子, 坂崎善門 : malignant calcifying epithelioma. 西日本皮膚 科, 46: 637-638, 1984.

12) 佐藤俊次, 新井克志, 関根るみ子, 早稲田豊美, 石橋 明, 藤田恵一, 向井 清: 悪性変化した 石灰化上皮腫の 1 例. 形成外科, 28：48-51, 1985. 